\title{
The New Strategies for the Textile and Fashion Project
}

\author{
Sandra H da Silva Santis* \\ University São Paulo, Brazil \\ *Corresponding author: Sandra H da Silva Santis, University São Paulo, Brazil \\ Submission: 眥 February 07, 2018; Published: 眥 March 19, 2018
}

\begin{abstract}
The purpose of the study is to reflect on the methods used by the manufacturing that provide subsidy for the construction of the product and also, to meet the need of customers. In this context, the intention, therefore, is to judge, design methodologies that help the process of creativity and innovation to improve the fabric. The research developed through the bibliographical reference, intends to analyze and reflect on the methodologies applied to textile and fashion design for product development.
\end{abstract}

\section{Introduction}

The textile and fashion design for all people is considered the fruit of creativity or the individual creative process. In recent years, several methodologies have been used to modify the practice of the creative process to encourage the use of collaborative dynamics. In textile and fashion manufacturing, much research is developed to enhance the creative process, modify and create new styles. The changes in technology and in the planning of the productive process have been much discussed in several areas of the market, a problem that calls attention is to understand: what methodologies are being used to develop human creative processes in textile and fashion design? This issue becomes important to increase knowledge of this expanding area.

The objective of this study is to promote a reflection through the literature review on the new methodologies used in the textile and fashion product design. This bibliographic review study done by articles, book and website.

Authors and researchers in engineering and design in textiles and fashion have developed work to create sustainable methods in different approaches. The intention is to provide innovation, improvement and creative development for textile and fashion products and services. In any case, this process is being developed with several methodologies for creative incentives, such as: design methodology, design thinking and collaborative creation.

\section{Project methodology}

In general, manufacturing Textile and Fashion In its creative design structure seeks solutions for issues that undergo cognition, creativity, innovation and technology with high complexity.

Ostrower [1] states that the ability to understand, assimilate, set up and signify is the creative act. Create is a way to establish a new relationship between the human mind and the object in order to understand the meaning or Resign (Give a new meaning, a new practice, ability to perceive an object by a different view).

Lobach [2] states that the project consists of a systematic plan or method that includes problem solving incorporating ideas, innovation, sketch creation, samples and models for make concrete the solution found.

The project methodologies in the industrial area are to be faced as part of the process. For this reason a study in a textile company contributes to adapt to the standards, practices and tools that are used to maintain the quality of products and services. The creation procedure promotes finding strategies that encourage the production of new mixing the components, which can motivate, add capacity and add value to the basic, Santis [3].

Bouer and Carvalho (2005) claim that project methodologies have become if important as tools, methods, theories and practices that aggregate Value to the creative process. For the incentive of the creative process can be cited tools like: Minds model, conceptual map, diagram of Fast, functional analysis, axiomatic project and others. This tools help in the development and creation of products, in addition other philosophies As Design Thinking It has also been very publicized.

\section{Design thinking}

The Design Thinking it focuses on promoting the well-being of people consists of a multidisciplinary, collaborative, innovative methodology that seeks to promote solutions for the creation of products and services. Combines a set of tools, techniques, and methods to seek new prospects for solutions to problems in projects and in the creative process. 
Second Kimbell [4], the Design Thinking It lists three main concepts: design thinking as a cognitive style, as a general theory of design and as a resource for organizations to promote innovative solutions in design. The design Thinking It has several tools that should be applied in order to create a new solver perspective and often counts on the collaborative work process of ideas.

\section{Collaborative creation}

A widely used trend for product development is collaborative creation or co-creation is to work together, manage the opinions of a professional project or even develop with the collaboration of the team. Authors like $[5,6]$ and others discuss about the promotion of co-creation in the textile design environment. This methodology has helped in product design or design, encourages learning and helps reduce process difficulties or errors. Collaborative design promotes product development with a broader view through team participation or multiple opinions can be undertaken by focus group or Brainstorning [7-12].

\section{Metodology}

The data collected through research using secondary source (books, articles and magazines) that were used as information base and provide the necessary elucidations for the rationale [18-20].

\section{Final considerations}

Several studies on the development of project methodologies show the application of methodologies as a strategy that, together with several tools, helps in the creation of products and in the creative process [21]. The new methodologies seek to promote the association of techniques that provide greater reliability to the project process and also promote the collaborative creation, cocreation and exchange of ideas, use of theories and the use of tools [22]. In short, changes in any form, boom, increase improvements, innovation and knowledge sharing to develop products through the use of project strategies.

\section{References}

1. Ostrower F (1978) Creativity and creation processes.

2. Lobach B (2001) Design industrial: Bases for the configuration. Rio de Janeiro: Edgard Blücher Ltda.

3. Sandra Helena da Silva S (2017) Strategy of textile design: Use of design methodology tools in the creative process. Strategic Design Research Journal 10(1): 57-66

4. Kimbell L (2011) Rethink design thinking: Part I. design and culture. The
Journal of the Design Studies Forum 3(3): 285-306.

5. Mazzarella F, Mitchell V, Escobar TC (2017) Crafting sustainable futures. the value of the service designer in activating meaningful social innovation from within textile artisan communities. The Design Journal 20(1): S2935-S2950.

6. Hirscher AL, Niinimäki K, Armstrong CMJ (2018) Social manufacturing in the fashion sector: New value creation through alternative design strategies?. Journal of Cleaner Production 172: 4544-4554.

7. Cross N (2006) Fortyyearsof design research. Design Research Quarterly 1:3-5.

8. Chai KH, Zhang J, Tan KC (2005) A TRIZ-based method for new service design. Journal of Service Research 8(1): 48-66.

9. Da Silva, Dailene N, Dos Santos MM (2013) Textile Design: Historical Review, Emergence and Evolution of Technologies.

10. Dos Santos MM, Paschoarelli LC (2009) Design and planning: technological aspects, UNESP.

11. (2016) Sectorial Report of the Brazilian Textile Industry. Sao Paulo:IEMI, France.

12. Kalkan A, Özlem ÇB, Mutlu A (2014) The impacts of intellectual capital, innovation and organizational strategy on firm performance. ProcediaSocial and Behavioral Sciences 150: 700-707.

13. Kucharčíková A, Tokarčíková E, Blašková M (2015) Human capital management aspect of the human capital efficiency in university education. Procedia-Social and Behavioral Sciences 177: 48-60.

14. Leonard A (2011) History of things: from nature to trash, what happens to everything we consume, Rio de Janeiro: Zahar.

15. Mete F (2006) The creative role of sources of inspiration in clothing design. International Journal of Clothing Science and Technology 18(4): 278-293.

16. Morin E (2011) Introduction to complex thinking. Porto Alegre: Sulina Publishing House. In: Okabe EP (Ed.), Project methodology for the development of vehicular suspension.

17. Roy, Goutam SD (2012) Designing office shirt: an integrated approach. Journal of Fashion Marketing and Management: An International Journal 16(3): 327-341.

18. Sanches, Regina A (2010) Technology applied to articles of clothing intended for sports.

19. Sandra Helena da Silva S (2016) The use of design methodology tools for the creative process in textile products-ENPMODA 2016: National Meeting of Fashion Research, School of Arts, Sciences and Humanities, Universidade São Paulo, Brazil.

20. Sandra Helena da Silva S (2016) Project methodology applied to smart fabrics. Journal of Textile and Fashion 2: 7-17.

21. Vianna C, Quaresma M (2015) Ergonomics: comfort textile noble wear of the elderly. Blucher Design Proceedings 2: 1662-1670.

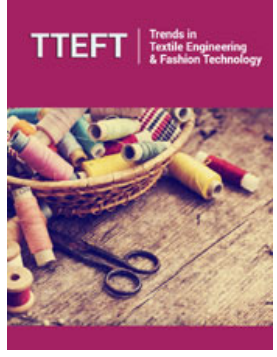

Trends in Textile Engineering \& Fashion Technology

\section{Benefits of Publishing with us}

- High-level peer review and editorial services

- Freely accessible online immediately upon publication

- Authors retain the copyright to their work

- Licensing it under a Creative Commons license

- Visibility through different online platforms 